\title{
PENGARUH KEMATANGAN EMOSI, RELIGIUSITAS, KEPERCAYAAN DIRI, SOSIAL EKONOMI KELUARGA, DAN LINGKUNGAN SEKOLAH TERHADAP MOTIVASI BELAJAR SISWA IPS DI SMA NEGERI 13 PADANG
}

\author{
Sarita Ramli, Syailendra Eka Saputra, Sri Wahyuni \\ Program Studi Pendidikan Ekonomi STKIP PGRI Sumatera Barat \\ saritaramli1996@gmail.com
}

\begin{abstract}
This study aims to analyze the influence of classroom management, students' learning interests, mobile phone usage, confidence and parenting patterns stimultan to the learning achievements of grade VII students of SMP Negeri 3 Palembayan. The results showed that: (1) there was a significant influence between partial classroom management on student learning achievement with a coefficient score of 0.137 , a thitung score of $3,197>$ ttabel of 1,998 ; (2) there is a significant influence between students' partial learning interest in student learning achievement with a coefficient of 0.181 , a value of $4,728>$ ttabel of 1,998 ; (3) there is a significant influence on the partial use of mobile phones on student learning achievement with a coefficient of 0.175 , a value of $6,089>$ ttabel of 1,998 ; (4) there is a significant influence of partial confidence on student learning achievement with a coefficient of 0.073 and a thitung score of 2,453>ttabel of 1,998 ; (5) there is a significant influence of partial parental parenting patterns on student learning achievement with a coefficient score of 0.089 and a thitung score of 2,204>ttabel of 1,998; (6) there is a significant influence between classroom management, student learning interests, mobile phone use, self-confidence and parenting patterns stimultan to student learning achievement with a Tcalculate of 44,331>Ftabel2.52.
\end{abstract}

Keywords: Learning Achievement, Classroom Management, Learning Interests, Mobile Use, Confidence, Parenting Patterns.

\section{PENDAHULUAN}

Pendidikan merupakan kegiatan antar manusia, oleh manusia dan untuk manusia. Menurut Dalyono dalam (Setyaningsih, Setiani, \& Jayadi, 2019) menyatakan bahwa motivasi belajar dipengaruhi oleh beberapa faktor yaitu faktor internal yang meliputi kesehatan, intelegensi, bakat minat, motivasi dan cara belajar, kemudian faktor eksternal yang meliputi keluarga, sekolah, masyarakat, dan lingkungan sekolah. 
Dalam proses belajar, motivasi perlu ditumbuh dan dikembangkan, karena tanpa adanya faktor pendorong siswa untuk berbuat utnuk menyenangi dalam mengikuti setiap mata pelajaran akan menimbulkan sikap malas pada siswa dan akibatnya ilmu pengetahuan dan

Tabel 1. Data Rata-rata UN SMA Negeri di Kec. Koto Tangah Tahun Pelajaran 2018/2019

\begin{tabular}{ccccc}
\hline No. & Nama Sekolah & Akreditasi & Jumlah Peserta & Rata-rata UN \\
\hline 1 & SMA Negeri 7 PADANG & $\mathrm{A}$ & 87 & 54,92 \\
2 & SMA Negeri 8 PADANG & $\mathrm{A}$ & 118 & 51,93 \\
3 & SMA Negeri 13 PADANG & $\mathrm{A}$ & 106 & 48,2 \\
& Koto Tangah & & 311 & 51,68 \\
\hline
\end{tabular}

Sumber: Hasilun.puspendik.kemendikbud.go,id

Dari tabel diatas dapat disimpulkan bahwa alasan penulis memilih SMA Negeri 13 Padang sebagai objek penelitian dengan alasan jika dilihat dari proses pencapaian siswaternyata nilai UN siswa pada SMA Negeri 13 Padang diduga cukup rendah dari ke tiga sekolah yang ada di Kec. Koto Tangah. Hal ini dapat dilihat dari SMA Negeri 13 Padang yang memiliki jumlah siswa yaitu 106 siswa dengan bobot rata-rata nilai UN sebesar 48,2 sementara SMA Negeri 7 Padang memiliki jumlah keterampilan yang diberikan tidak dapat dikuasai dengan baik sehingga tujuan pendidik tidak tercapai.

Berikut disajikan data tabel nama-nama SMA Negeri beserta capaian hasil UN SMP Negeri yang berada di Kecamatan Koto Tangah : 
bisa menumbuhkan semangat dalam belajar. "Emosi dapat berfungsi sebagai motif yang dapat memotivasi atau menyebabkan timbulnya semacam kekuatan agar individu dapat berbuat atau bertingkah laku "(Sulistyowati, 2016). Selanjutnya, salah satu faktor internal yang diduga mempengaruhi prestasi belajar adalah religiusitas. Seperti yang diungkapkan oleh Hardjana dalam (Ghufron \& Risnawita, 2010) religiusitas adalah perasaan dan kesadaran akan hubungan dan ikatan kembali dengan Allah. Religiusitas menunjuk pada tingkat ketertarikan individu terhadap agamanya dengan menghayati dan menginternalisasikan ajaran agamanya sehingga berpengaruh dalam segala tindakan dan pandangan hidupnya. Karna dengan adanya religiusitas yang tinggi pada diri seseorang akan berpengaruh pada segala tindakan dan pandangan hidupnya.

Selain faktor internal, Percaya diri adalah berbuat dengan penuh keyakinan. Apa pun tantangan yang dihadapi dan dalam kondisi apapun ia akan menggapai cita-citanya.Siswa yang percaya diri memiliki memiliki rasa optimis dengan kelebihan yang dimiliki dalam mencapai tujuan yang telah ditetapkan (Fitri, Zola, \& Ifdil, 2018).

Faktor selanjutnya yang diduga mempengaruhi motivasi belajar adalah sosial ekonomi keluarga. Hasil Penelitian Djafar dalam (Fuady, 2016) mengungkapkan bahwa kondisi sosila ekonomi keluarga mempunyai pengaruh terhadap motivasi belajar anak, dengan asumsi bahwa faktor-faktor di luar daripada variabel-variabel yang diteliti dianggap konstan atau tidak berubah. Salah satu indikator sosial ekonomi keluarga adalah pendidikan.

Selain faktor sosial ekonomi keluarga diduga faktor yang mempengaruhi motivasi belajar adalah lingkungan sekolah. Lingkungan sekolah adalah rumah kedua setelah rumah orang tua. Siswa lebih banyak menghabiskan waktu di sekolah dari pada tempat lainnya. Menurut Dalyono dalam (Nurjanah, 2012) menyatakan 
Vol. 1 No. 2 (Mei 2021) (305-323)

bahwa, sekolah sangat berperan dalam meningkatkan pola pikir anak, karena di sekolah mereka dapat belajar bermacam-macam ilmu pengetahuan.

Berdasarkan latar belakang permasalahan diatas, maka peneliti tertarik untuk melakukan penelitian tentang "Pengaruh Kematangan Emosi, Religiusitas, Kepercayaan diri, Sosial Ekonomi Sekolah dan Lingkungan sekolah terhadap motivasi belajar siswa kelas XII IPS di SMA Negeri 13 Padang".

Penelitian ini bertujuan untuk mengetahui pengaruh:

1. Pengaruh kematangan emosi terhadap motivasi belajar siswakelas XII IPS di SMA Negeri 13 Padang.

2. Pengaruh religiusitas terhadap motivasi belajar siswa kelas XII IPS di SMA Negeri 13 Padang.

3. Pengaruh kepercayaan diriterhadap motivasi belajar siswakelas XII IPS di SMA Negeri 13 Padang.

4. Pengaruh sosial ekonomi keluaraga terhadap motivasi belajar siswakelas XII IPS di SMA Negeri 13 Padang.

5. Pengaruh lingkungan sekolah terhadap motivasi belajar siswakelas XII IPS di SMA Negeri 13 Padang.

6. Pengaruh kematangan emosi, religiusitas, kepercayaan diri, sosial ekonomi keluarga dan lingkungan sekolah secara bersama-sama terhadap motivasi belajar siswa kelas XII IPS di SMA Negeri 13 Padang.

Menurut Hamalik dalam (Eva Dwi L, dkk 2019:302-317) motivasi perubahan energi dalam diri atau pribadi seseorang yang ditandai dengan timbulnya perasaan dan reaksi untuk mencapai tujuan.Sejalan dengan yang dikemukakan oleh Gates dalam (Sholibat, 2015:15) bahwa motivasi adalah suatu kondisi fisiologis dan psikologis yang terdapat dalam diri seseorang yang mengatur tindakannya dengan cara tertentu. Motivasi dibedakan menjadi dua yaitu motivasi intrinsik, dan ekstr insik. Motivasi yang lebih berperan penting bagi murid adalah motivasi intrinsik, karena lebih 
konsisten dan tidak tergantung pada pengaruh orang lain Syah dalam (Aniyatin \& Mahrudin, 2017:71).

Menurut Chaplin (Aridhona, 2017:224-233) kematangan emosi atau disebut dengan emotional maturity adalah satu keadaan atau kondisi mencapai tingkat kedewasaan dari perkembangan emosional dan karena itu pribadi yang bersangkutan tidak lahir menampilkan pola emosional yang pantas bagi anak-anak. Menurut Hurlock dalam (Ulfah dan Syahrizaldi, 2017:59-65) juga mengatakan bahwa remaja yang memiliki kematangan emosi apabila remaja tidak meledakkan emosinya dihadapan oranglain dan mampu menunggu saat dan tempat yang tepat untuk mengungkapkan emosinya, mampu memahami emosi diri sendiri, memahami yang sedang dirasakan dan mengetahui penyebab dari emosi yang dihadapi individu tersebut dapat menilai situasi secara kritis terlebih dahulu sebelum bereaksi secara emosional, kemudian memutuskan bagaimana cara bereaksi terhadap situasi tersebut sehingga tidak seperti anak-anak yang beraksi tanpa berfikir.

Pengertian religiusitas berdasarkan dimensi-dimensi yang dikemukan oleh Glock dan Stark dalam (Pontoh \& Farid, 2015:100) adalah seberapa jauh pengetahuan, seberapa kokoh keyakinan, seberapa tekun pelaksanaan ibadah dan seberapa dalam penghayatan agama yang dianut seseorang. Nilai religius disini dapat dipahami sebagai nilainilaikehidupan yangmencerminkan tumbuh-kembangnya kehidupan beragama yang terdiri dari tiga unsur pokok yaitu aqidah, ibadah, dan akhlak yang menjadi pedoman perilaku sesuai dengan aturan-aturan Illahi untuk mencapai kesejahteraan serta kebahagiaan hidup di dunia dan akhirat (Nurmayanti, 2019:53).

Menurut Afiatin dan Andayanidalam kepercayaan diri merupakan aspek kepribadian yang berisi keyakinan tentang kekuatan, kemampuan dan keterampilan yang dimilikinya. Seseorang yang memiliki kepercayaan diri biasanya menganggap bahwa dirinya mampu melakukan segala sesuatu yang 
Vol. 1 No. 2 (Mei 2021) (305-323)

dihadapinya dengan kemampuan yang dimilikinya. Kepercayaan diri adalah kemampuan untuk memercayai kemampuan sendiri .

Dalam konsep sosial ekonomi yang lain, menurut Abdulsyani dalam sosial ekonomi merupakan kedudukan atau posisi seseorang dalam kelompok manusia yang ditentukan oleh jenisaktivitas ekonomi, pendapatan, tingkat pendidikan, tipe rumah tinggal, pemilikan kekayaan atau fasilitas, jenis kegiatan dalam berbagai organisasi. Menurut Joublish dan Muhammad (2010:678) menujukkan bahwa anak dari keluarga yang lemah status sosial ekonominya memiliki kesiapan yang rendah daripada teman sebaya mereka dari keluarga yang menengah ke atas status sosial ekonominya.

Imam Supardi dalam menyatakan "lingkungan adalah jumlah semua benda hidup dan mati serta seluruh kondisi yang ada di dalam ruang yang kita tempati".Lingkungan sekolah turut mempengaruhi tingkat keberhasilan belajar siswa.Sekolah merupakan suatu lembaga khusus, suatu wahana, suatu tempat untuk menyelenggarakan pendidikan, yang didalamnya terdapat suatu proses belajar mengajar untuk mencapai tujuan pendidikan tertentu .

\section{METODE PENELITIAN}

Jenis penelitian ini adalah berupa asosiatif.Penelitian ini dilakukan di SMA Negeri 13 Padang dan telah dilaksankan pada bulan Januari sampai selesai. Populasi adalah seluruh siswa kellas XI SMA Negeri 13 Padangyang terdaftar pada tahun 2019-2020 yang berjumlah 132 orang.

Variabel peneliti terbagi dalam dua variabel yaitu variable independen dan variabel yang mempengaruhi atau yang menjadi sebab perubahannya atau timbulnya variabel dependent (terikat) adapun yang menjadi variabel dependen atau variabel terikat adalah Motivasi Belajar (Y) dan variabel terikat Kematangan Emosi (X1), Religiusitas (X2), Kepercayaan Diri (X3), Sosial Ekonomi Keluarga (X4), Lingkungan Sekolah (X5). 
Teknik analisis data yang digunakan untuk menguji hipotesis adalah analisis regresi linear berganda.

\section{HASIL DAN PEMBAHASAN}

1. Sampel keseluruhan.

Tabel 2. Hasil Analisis Regresi Berganda

\begin{tabular}{|c|c|c|c|c|c|}
\hline \multicolumn{6}{|c|}{ Coefficients $^{\mathrm{a}}$} \\
\hline \multirow{2}{*}{ Model } & \multicolumn{2}{|c|}{$\begin{array}{l}\text { Unstandardized } \\
\text { Coefficients }\end{array}$} & \multirow{2}{*}{$\begin{array}{l}\text { Standardized } \\
\text { Coefficients } \\
\text { Beta }\end{array}$} & \multirow{2}{*}{$\mathrm{T}$} & \multirow{2}{*}{ Sig. } \\
\hline & $\mathrm{B}$ & $\begin{array}{l}\text { Std. } \\
\text { Error }\end{array}$ & & & \\
\hline 1 (Constant) & 53.452 & 2.654 & & 20.140 & .000 \\
\hline Kematangan emosi & .257 & .045 & .313 & 5.739 & .000 \\
\hline Religiusitas & .264 & .041 & .414 & 6.388 & .000 \\
\hline Kepercayaan diri & .170 & .057 & .191 & 2.982 & .004 \\
\hline $\begin{array}{l}\text { Sosial ekonomi } \\
\text { keluarga }\end{array}$ & .140 & .046 & .177 & 3.040 & .003 \\
\hline $\begin{array}{l}\text { Lingkungan sekolah } \\
\text { a. Dependent Variable: }\end{array}$ & $\begin{aligned} .124 \\
\text { AR00006 }\end{aligned}$ & .032 & .245 & 3.900 & .000 \\
\hline
\end{tabular}

Sumber: Olahan Data Primer, 2021

Berdasarkan hasil yang terdapat pada tabel di atas, maka dapat dirumuskan persamaan regresi linear berganda sebagai berikut:

$$
\begin{aligned}
& Y= a+b_{1} X_{1}+b_{2} X_{2}+b_{3} X_{3}+b_{4} X_{4}+ \\
& b_{5} X_{5}+e
\end{aligned}
$$

1) Nilai konstanta sebesar 53,425 berarti tanpa adanya pengaruh dari variabel bebas maka nilai variabel terikat nilainya hanya sebesar 53,425 satuan. Hal ini berarti bahwa apabila variabel
Analisis regresi berganda dalam penelitian ini dilakukan dengan menggunakan bantuan program SPSS Versi 24.0 dapat dilihat pada Tabel dibawah ini: 
Vol. 1 No. 2 (Mei 2021) (305-323)

3) Koefesien regresi religiusitas (X2) diketahui bernilai sebesar 0,264. Dapat diartikan, apabila religiusitasmeningkat sebesar satu satuan dan variabel bebas lain tetap, maka motivasi belajar siswaakanmeningkat sebesar 0,264 . satuan.

4) Koefesienregresi kepercayaan diri (X3) diketahui bernilai sebesar 0,170. Dapat diartikan, apabila kepercayaan dirimeningkat sebesar satu satuan dan variabel bebas lain tetap, maka motivasi belajar siswaakan meningkat sebesar 0,170 . satuan.

5) Koefesien regresi sosial ekonomi keluarga (X4) diketahui bernilai sebesar 0,140. Dapat diartikan, apabila sosial ekonomi keluarga meningkat sebesar satu satuan dan variabel bebas lain tetap, maka motivasi belajar siswa akan meningkatsebesar 0,140 satuan.

6) Koefesien regresi komformitas lingkungan sekolah (X5) diketahui bernilai sebesar 0,124. Dapat diartikan, apabila lingkungan sekolah meningkat sebesar satu satuan dan variabel bebas lain tetap, maka motivasi belajar siswaakanmeningkat sebesar 0,124satuan

1. Pengaruh kematangan emosi $\left(\mathrm{X}_{1}\right)$ terhadap motivasi belajar siswa IPS di SMA Negeri 13 Padang

Berdasarkan pendapatan tinggi dapat diketahui secara parsial kematangan emosi berpengaruh signifikan terhadap motivasi belajar siswa di SMA N 13 Padang. Hal ini dibuktikan dengan hasil penelitian yang menunjukkan bahwa nilai koefisiennya sebesar 0,241 dan nilai $t_{\text {hitung }} 3,001>t_{\text {tabel }} 2,01174$ yang berarti $\mathrm{H}_{0}$ ditolak dan $\mathrm{H}_{\mathrm{a}}$ diterima. Artinya apabila kematangan emosi meningkat sebesar satu satuan, maka motivasi belajar akan meningkat 0,241

Berdasarkan pendapatan rendah dapat diketahui secara parsial kematangan emosi berpengaruh signifikan terhadap motivasi belajar siswa di SMA N 13 Padang. Hal ini dibuktikan dengan hasil penelitian yang menunjukkan bahwa nilai 
koefisiennya sebesar 0,310 dan nilai $\mathrm{t}_{\text {hitung }} 5,815>\mathrm{t}_{\text {tabel }} 2,01537$ artinya $\mathrm{H}_{0}$ ditolak dan $\mathrm{H}_{\mathrm{a}}$ diterima. Artinya apabila kematangan emosi meningkat sebesar satu satuan, maka motivasi belajar akan meningkat 0,310 .

\section{Berdasarkan pendapatan}

keseluruhan pengujian hipotesis diketahui bahwa secara parsial kematangan emosi berpengaruh signifikan terhadap motivasi belajar siswadi SMA N13 Padang.Hal ini dibuktikan dengan hasil penelitian yang menunjukkan bahwa nilai koefisiennya sebesar 0,257 dan nilai $\mathrm{t}_{\text {hitung }} 5,739>\mathrm{t}_{\text {tabel }} 1,98638$ artinya $\mathrm{H}_{0}$ ditolak dan $\mathrm{H}_{\mathrm{a}}$ diterima. Artinya apabila kematangan emosi meningkat sebesar satu satuan, maka motivasi belajar akan meningkat 0,257 .

Hasil penelitian ini mendukung penelitian sebelumnya yang dilakukan oleh (Aniyatin, dkk 2017) mengatakan hasil penelitian menunjukan bahwa kematangan emosi belajar memiliki pengaruh signifikan terhadap motivasi belajar. Sama halnya dengan hasil penelitian muhamad farhan yang mengatakan ada pengaruh signifikan antara kecerdassan emosisonal terhadap motivasil belajar. Jika emosi lepas kendali dapat membuat orang pandai menjadi bodoh, tanpa kematangan emosi orang tidak akan mampu mengembangkan kemampuan kognitifnya dan secara tidak langsung akan mempengaruhi motivasil belajarnya. Hal ini bertolak belakang dengan hasil penelitian yang dilakukan oleh Dinda Asa tahun 2017 yang menyatakan secara parsial kematangan emosi tidak memberikan pengaruh terhadap motivasi belajar.

2. Pengaruh religiusitas terhadap motivasi belajar siswa IPS di SMA Negeri 13 Padang

Berdasarkan pendapatan tinggi dapat diketahui secara parsial religiusitas berpengaruh signifikan terhadap motivasi belajar siswa di SMA N 13 Padang. Hal ini dibuktikan dengan hasil penelitian yang menunjukkan bahwa nilai koefisiennya sebesar 0,300 dan nilai $\mathrm{t}_{\text {hitung }} 4,221>\mathrm{t}_{\text {tabel }} 2,01174$ artinya $\mathrm{H}_{0}$ ditolak dan $\mathrm{H}_{\mathrm{a}}$ diterima. Artinya 
Vol. 1 No. 2 (Mei 2021) (305-323)

apabila religiusitas meningkat sebesar satu satuan, maka motivasi belajar akan meningkat 0,300 .

Berdasarkan pendapatan rendah dapat diketahui secara parsial religiusitas berpengaruh signifikan terhadap motivasi belajar siswa di SMA N 13 Padang. Hal ini dibuktikan dengan hasil penelitian yang menunjukkan bahwa nilai koefisiennya sebesar 0,136 an nilai $\mathrm{t}_{\text {hitung }} 2,199>\mathrm{t}_{\text {tabel }} 2,01537$ artinya $\mathrm{H}_{0}$ ditolak dan $\mathrm{H}_{\mathrm{a}}$ diterima. Artinya apabila religiusitas meningkat sebesar satu satuan, maka motivasi belajar akan meningkat 0,136

Berdasarkan pendapatan keseluruhan dapat diketahui secara parsial religiusitas berpengaruh signifikan terhadap motivasi belajar siswa di SMA N 13 Padang. Hal ini dibuktikan dengan hasil penelitian yang menunjukkan bahwa nilai koefisiennya 0,264 dan nilai $\mathrm{t}_{\text {hitung }} 6,388>\mathrm{t}_{\text {tabel }} 1,98638$ artinya $\mathrm{H}_{0}$ ditolak dan $\mathrm{H}_{\mathrm{a}}$ diterima. Artinya apabila religiusitas meningkat sebesar satu satuan, maka motivasi belajar akan meningkat 0,264
Hasil penelitian ini mendukung penelitian sebelumnya yang dilakukan oleh (Erna Dewi, 2017) menunjukkan bahwa terdapat pengaruh religiusitas terhadap motivasi belajar siswa. Penelitian serupa juga dilakukan oleh arkhina dwi tahun 2013 mengatakan ada hubungan signifikan atara religiusitas dengan motivasi belajar siswa.

3. Pengaruh kepercayaan diri terhadap motivasi belajar siswa IPS di SMA Negeri 13 Padang

Berdasarkan pendapatan tinggi dapat diketahui bahwa secara parsial kepercayaan diri berpengaruh signifikan terhadap motivasi belajar siswa di SMA N 13 Padang. Hal ini dibuktikan dengan hasil penelitian yang menunjukkan bahwa nilai koefisiennya sebesar 0,178 dan nilai bahwa $\mathrm{t}_{\text {hitung }} 2,471>\mathrm{t}_{\text {tabel }} 2,01174$ artinya $\mathrm{H}_{0}$ ditolak dan $\mathrm{H}_{\mathrm{a}}$ diterima. Artinya apabila kepercayaan diri meningkat sebesar satu satuan maka motivasi belajar juga akan meningkat sebesar 0,178

Berdasarkan pendapatan rendah dapat diketahui bahwa secara parsial kepercayaan diri berpengaruh 
signifikan terhadap motivasi belajar siswa di SMA N 13 Padang. Hal ini dibuktikan dengan hasil penelitian yang menunjukkan bahwa nilai koefisiennya sebesar 0,218 dan nilai $\mathrm{t}_{\text {hitung }} 2,170>\mathrm{t}_{\text {tabel }} 2,01537$ artinya $\mathrm{H}_{0}$ ditolak dan $\mathrm{H}_{\mathrm{a}}$ diterima. Artinya apabila kepercayaan diri meningkat sebesar satu satuan maka motivasi belajar juga akan meningkat sebesar 0,218 .

\section{Berdasarkan pendapatan} keseluruhan dapat diketahui bahwa secara parsial kepercayaan diriberpengaruh signifikan terhadap motivasi belajar siswa di SMA N 13 Padang. Hal ini dibuktikan dengan hasil penelitian yang menunjukkan bahwa nilai koefisien sebesar 0,170 dan nilai $\mathrm{t}_{\text {hitung }} 2,982>\mathrm{t}_{\text {tabel }} 1,98638$ artinya $\mathrm{H}_{0}$ ditolak dan $\mathrm{H}_{\mathrm{a}}$ diterima. Artinya apabila kepercayaan diri meningkat sebesar satu satuan maka motivasi belajar juga akan meningkat sebesar 0,170 .

Hasil penelitian ini mendukung penelitian sebelumnya yang dilakukan oleh (Aryani yunita, 2020) bahwa hasil penelitiannya menunjukkan bahwa terdapat pengaruh kepercayan diri terhadap motivasi belajar siswa.

4. Pengaruh sosial ekonomi keluarga terhadap motivasi belajar siswa IPS di SMA Negeri 13 Padang.

Berdasarkan pendapatan tinggi dapat diketahui bahwa secara parsial sosial ekonomi keluargaberpengaruh signifikan terhadap motivasi belajar siswa di SMA N 13 Padang. Hal ini dibuktikan dengan hasil penelitian yang menunjukkan bahwa nilai koefisiennya sebesar 0,190 dan nilai $\mathrm{t}_{\text {hitung }} 2,831>\mathrm{t}_{\text {tabel }} 2,01174$ artinya $\mathrm{H}_{0}$ ditolak dan $\mathrm{H}_{\mathrm{a}}$ diterima. Artinya apabila sosial ekonomi keluarga meningkat sebesar satu satuan maka motivasi belajar akan meningkat sebesar 0,190.

Berdasarkan pendapatan rendah dapat diketahui bahwa secara parsial sosial ekonomi keluargaberpengaruh signifikan terhadap motivasi belajar siswa di SMA N 13 Padang. Hal ini dibuktikan dengan hasil penelitian yang menunjukkan bahwa nilai koefiennya sebesar 0,138 dan nilai $t_{\text {hitung }} 2,017>t_{\text {tabel }} 2,01537$ artinya $\quad H_{0}$ ditolak dan $\mathrm{H}_{\mathrm{a}}$ diterima. Artinya 
apabila sosial ekonomi keluarga meningkat sebesar satu satuan maka motivasi belajar akan meningkat sebesar 0,138 .

Berdasarkan pendapatan keseluruhan dapat diketahui bahwa secara parsial sosial ekonomi keluargaberpengaruh signifikan terhadap motivasi belajar siswa di SMA N 13 Padang.Hal ini dibuktikan dengan hasil penelitian yang menunjukan bahwa nilai koefiennnya sebesar 0,140 dan nilai $t_{\text {hitung } 3,040>} t_{\text {tabel }} 1,98638$ artinya $H_{0}$ ditolak dan $\mathrm{H}_{\mathrm{a}}$ diterima. Artinya apabila sosial ekonomi keluarga meningkat sebesar satu satuan maka motivasi belajar akan meningkat sebesar 0,140 .

Hasil penelitian ini mendukung penelitian sebelumnya yang dilakukan oleh (Nurul Senja, 2017) yang mengatakan hasil penelitiannya menunjukkan bahwa terdapat pengaruh sosial ekonomi keluarga terhadap motivasi belajar siswa. Penelitian serupa juga dilakukan oleh Ifdianto Anggi bawha terdapat pengaruh positif antara sosial ekonomi orang tua terhadap motivasi belajar siswa.

5. Pengaruh lingkungan Sekolah Terhadap Motivasi Belajar Siswa Kelas XII IPS di SMA N 13 Padang.

Berdasarkan pendapatan tinggi dapat diketahui bahwa secara parsial lingkungan sekolah berpengaruh signifikan terhadap motivasi belajar siswa di SMA N 13 Padang.Hal ini dibuktikan dengan hasil penelitian yang menunjukkan bahwa nilai koefisiennya sebesar 0,122 dan nilai $t_{\text {hitung }} 2,756>t_{\text {tabel }}$ 2,01174artinya $\mathrm{H}_{0}$ ditolak dan $\mathrm{H}_{\mathrm{a}}$ diterima. Artinya apabila lingkungan sekolah meningkat sebesar satu satuan maka motivasi belajar juga akan meningkat sebesar 0,122 .

Berdasarkan pendapatan rendah dapat diketahui bahwa secara parsial lingkungan sekolah berpengaruh signifikan terhadap motivasi belajar siswa di SMA N 13 Padang.Hal ini dibuktikan dengan hasil penelitian yang menunjukkan bahwa nilai koefisiennya sebesar 0,121 dan nilai $\mathrm{t}_{\text {hitung }} 2,557>\mathrm{t}_{\text {tabel }} 2,01537$ artinya $\mathrm{H}_{0}$ 
Vol. 1 No. 2 (Mei 2021) (305-323)

http://ejournal.stkip-pgri-sumbar.ac.id/index.php/horizon

ditolak dan $\mathrm{H}_{\mathrm{a}}$ diterima. Artinya apabila lingkungan sekolah meningkat sebesar satu satuan maka motivasi belajar juga akan meningkat sebesar 0,121

Berdasarkan pendapatan keseluruhan dapat diketahui bahwa secara parsial lingkungan sekolah berpengaruh signifikan terhadap motivasi belajar siswa di SMA N 13 Padang. Hal ini dibuktikan dengan hasil penelitian yang menunjukkan bahwa nilai koefisiennya sebesar 0,124bahwa nilai $\mathrm{t}_{\text {hitung }} 3,900>\mathrm{t}_{\text {tabel }} 1,98638$ artinya $\mathrm{H}_{0}$ ditolak dan $\mathrm{H}_{\mathrm{a}}$ diterima. Artinya apabila lingkungan sekolah meningkat sebesar satu satuan maka motivasi belajar juga akan meningkat sebesar 0,124 .

Hasil penelitian ini mendukung penelitian sebelumnya yang dilakukan oleh (Elok, dkk 2018) mengatakan hasil penelitian ini menunjukan bahwa lingkungan sekolah memiliki pengaruh signifikan terhadap motivasi belajar. Penelitian serupa juga dilakukan oleh Yulianawati tahun 2017 terdapat pengaruh signifikan antara lingkungan sekolah dengan motivasi belajar.

6. Pengaruh Kematangan Emosi, Religiusitas, Kepercayaan Diri, Sosial Ekonomi Keluarga dan Lingkungan Sekolah Secara Bersama-sama Terhadap Motivasi Belajar Sisawa IPS di SMA Negeri 13 Padang

Berdasarkan hasil uji hipotesis yang dilakukan secara bersama-sama ditemukan bahwa variabel Kematangan Emosi $\left(\mathrm{X}_{1}\right)$, Religiusitas $\left(\mathrm{X}_{2}\right)$ Kepercayaan Diri $\left(\mathrm{X}_{3}\right)$ Sosial Ekonomi Keluarga $\left(\mathrm{X}_{4}\right)$ Lingkungan Sekolah $\left(\mathrm{X}_{5}\right)$ berpengaruh signifikan terhadap Motivasi Belajar Siswa (Y) IPS di SMA Negeri 13 Padang. Analisis data dan pengujian hipotesis yang telah dilakukan untuk siswa dengan orang tua berpendapatan rendah diperoleh nilai $F_{\text {hitung }} 40,641>$ $\mathrm{F}_{\text {tabel }} 2,61$ dan nilai signifikan $0,000<$ $\alpha=0,05$ siswa dengan orang tua berpendapatan tinggi diperoleh nilai $F_{\text {hitung }} 17,495>F_{\text {tabel }} 2,59$ dan nilai signifikan $0,000<\alpha=0,05$ dan pedapatan secara keseluruhan diperoleh nilai $F_{\text {hitung }} 55,257>F_{\text {tabel }}$ 
Vol. 1 No. 2 (Mei 2021) (305-323)

2,48 dan nilai signifikan $0,000<$ 0,05. Dengan demikian dapat dikatakan bahwa (kematangan emosi, religiusitas, kepercayaan diri, sosial ekonomi keluarga dan lingkungan sekolah) berpengaruh signifikan terhadap motivasi belajar siswa.

Berdasarkan uraian di atas dapat dikatakan bahwa kematangan emosi, religiusitas, kepercayaan diri, sosial ekonomi keluarga dan lingkungan sekolah berpengaruh signifikan terhadap motivasi belajar siswa IPS di SMA Negeri 13Padang.

\section{KESIMPULAN}

Berdasarkan hasil analisis data yang telah dilakukan dapat disimpulkan sebagai berikut:

1. Kematangan emosi (X1) pada pendapatan keseluruhan diperoleh nilai koefisien sebesar 0,257 , nilai $\mathrm{t}_{\text {hitung }} 5,739>\mathrm{t}_{\text {tabel }}$ 1,98827 dan nilai signifikan $0,000<0,05$ yang berarti $\mathrm{H}_{0}$ ditolak dan $\mathrm{H}_{\mathrm{a}}$ diterima. Pada pendapatan tinggi nilai koefisiennya sebesar 0,241 , nilai $\mathrm{t}_{\text {hitung }} 3,001>\mathrm{t}_{\text {tabel }} 2,01174$ dan nilai signifikan $0,000<0,05$ yang berarti $\mathrm{H}_{0}$ ditolak dan $\mathrm{H}_{\mathrm{a}}$ diterima. Pada pendapatan rendah nilai koefisiennya sebesar 0,310 dan nilai $t_{\text {hitung }}$ $5,815>t_{\text {tabel }}$ 2,01537, nilai signifikan sebesar $0,000<0,05$ artinya $\mathrm{H}_{0}$ ditolak dan $\mathrm{H}_{\mathrm{a}}$ diterima. Artinya kematangan emosi berpengaruh signifikan terhadap motivasi belajar siswa kelas XII IPS di SMA N 13 Padang.

2. Religiusitas (X2) pada pendapatan keseluruhan diperoleh nilai koefisien sebesar 0,264 , nilai $t_{\text {hitung }} 6,388>t_{\text {tabel }}$ 1,98827 dan nilai signifikan $0,000<0,05$ yang berarti $\mathrm{H}_{0}$ ditolak dan $\mathrm{H}_{\mathrm{a}}$ diterima. Pada pendapatan tinggi nilai koefisiennya sebesar 0,300 , nilai $\mathrm{t}_{\text {hitung }} 4,221>\mathrm{t}_{\text {tabel }} 2,01174$ dan nilai signifikan $0,000<0,05$ yang berarti $\mathrm{H}_{0}$ ditolak dan $\mathrm{H}_{\mathrm{a}}$ diterima. Pada pendapatan rendah nilai koefisiennya sebesar 0,136 dan nilai $t_{\text {hitung }}$ 2,199> $t_{\text {tabel }} 2,01537$, nilai signifikan sebesar $0,034<0,05$ artinya $\mathrm{H}_{0}$ ditolak dan $\mathrm{H}_{\mathrm{a}}$ 
Vol. 1 No. 2 (Mei 2021) (305-323)

diterima. Artinya religiusitas berpengaruh signifikan terhadap motivasi belajar siswa kelas XII IPS di SMA N 13 Padang.

3. Kepercyaan diri(X3) pada pendapatan keseluruhan diperoleh nilai koefisien sebesar 0,170 , nilai $t_{\text {hitung }} 2,982>t_{\text {tabel }}$ 1,98827 dan nilai signifikan $0,004<0,05$ yang berarti $\mathrm{H}_{0}$ ditolak dan $\mathrm{H}_{\mathrm{a}}$ diterima. Pada pendapatan tinggi nilai koefisiennya sebesar 0,178 , nilai $\mathrm{t}_{\text {hitung }} 2,471>\mathrm{t}_{\text {tabel }} 2,01174$ dan nilai signifikan $0,018<0,05$ yang berarti $\mathrm{H}_{0}$ ditolak dan $\mathrm{H}_{\mathrm{a}}$ diterima. Pada pendapatan rendah nilai koefisiennya sebesar 0,218 dan nilai $t_{\text {hitung }}$ 2,170> $t_{\text {tabel }} 2,01537$, nilai signifikan sebesar $0,036<0,05$ artinya $\mathrm{H}_{0}$ ditolak dan $\mathrm{H}_{\mathrm{a}}$ diterima. Artinya kepercayaan diri berpengaruh signifikan terhadap motivasi belajar siswa kelas XII IPS di SMA N 13 Padang

4. Sosial ekonomi keluarga (X4) pada pendapatan keseluruhan diperoleh nilai koefisien sebesar
0,140 , nilai $\mathrm{t}_{\text {hitung }} 3,040>\mathrm{t}_{\text {tabel }}$ 1,98827 dan nilai signifikan $0,003<0,05$ yang berarti $\mathrm{H}_{0}$ ditolak dan $\mathrm{H}_{\mathrm{a}}$ diterima. Pada pendapatan tinggi nilai koefisiennya sebesar 0,190 , nilai $t_{\text {hitung }} 2,831>t_{\text {tabel }} 2,01174$ dan nilai signifikan $0,007<0,05$ yang berarti $\mathrm{H}_{0}$ ditolak dan $\mathrm{H}_{\mathrm{a}}$ diterima. Pada pendapatan rendah nilai koefisiennya sebesar 0,138 dan nilai $t_{\text {hitung }}$ $2,017>t_{\text {tabel }} 2,01537$, nilai signifikan sebesar 0,051>0,05 artinya $\mathrm{H}_{0}$ diterima dan $\mathrm{H}_{\mathrm{a}}$ ditolak.

5. Lingkungan sekolah (X5) pada pendapatan keseluruhan diperoleh nilai koefisien sebesar 0,124 , nilai $\mathrm{t}_{\text {hitung }} 3,900>\mathrm{t}_{\text {tabel }}$ 1,98827 dan nilai signifikan $0,004<0,00$ yang berarti $\mathrm{H}_{0}$ ditolak dan $\mathrm{H}_{\mathrm{a}}$ diterima. Pada pendapatan tinggi nilai koefisiennya sebesar 0,122 , nilai $t_{\text {hitung }} 2,756>t_{\text {tabel }} 2,01174$ dan nilai signifikan $0,019<0,05$ yang berarti $\mathrm{H}_{0}$ ditolak dan $\mathrm{H}_{\mathrm{a}}$ diterima. Pada pendapatan rendah nilai koefisiennya 
Vol. 1 No. 2 (Mei 2021) (305-323)

sebesar 0,121 dan nilai $t_{\text {hitung }}$ 2,557> $t_{\text {tabel }} 2,01537$, nilai signifikan sebesar $0,015<0,05$ artinya $\mathrm{H}_{0}$ ditolak dan $\mathrm{H}_{\mathrm{a}}$ diterima. Artinya kepercayaan diri berpengaruh signifikan terhadap motivasi belajar siswa kelas XII IPS di SMA N 13 Padang.

6. Kematangan emosi, religiusitas, kepercyaan diri, sosial ekonomi keluarga dan lingkungan sekolah secara bersama-sama berpengaruh signifikan terhadap motivasi belajar siswa kelas XII IPS di SMA N 13 Padang. Dimana diperoleh nilai $F_{\text {hitung }}$ $55,257>F_{\text {tabel }} 2,48$ dengan taraf signifikan $<0,05$. Hal ini berarti $\mathrm{H}_{\mathrm{a}}$ diterima dan $\mathrm{H}_{0}$ ditolak.Artinya semakin meningkat kematangan emosi, religiusitas, kepercayaan diri, sosial ekonomi keluarga, lingkungan sekolah maka motivasi belajar siswa akan meningkat.

\section{DAFTAR PUSTAKA}

Aniyatin, A., \& Mahrudin, A. (2017). Kecerdasan Emosional Berpengaruh Terhadap Motivasi Belajar Murid. Tadbir Muwahhid, 1(1), 71.

Aprilia Misnawati, J. W. (2013). Pengaruh Sosial Ekonomi Keluarga Dan Disiplin Belajar Terhadap Hasil Belajar Siswa Pada Mata Pelajaran Pengantar Ekonomi Kelas X Smk Widya Praja Ungaran Aprilia. Economic Education Analysis Journal, 2(1), 18-23.

Aridhona, J. (2017). Hubungan Antara Kecerdasan Spiritual Dan Kematangan Emosi Dengan Penyesuaian Diri Remaja. Intuisi : Jurnal Psikologi Ilmiah, 9(3), 224233.

Eva Dwi L , Muhsin, F. R. (2019). Pengaruh Lingkungan Keluarga, Disiplin Belajar, Kompetensi Sosial Guru, Dan Kesiapan Belajar Terhadap Motivasi Belajar Eva. Economic Education Analysis Journal, 2(1), 302-317.

Eva, W., \& Muhyadi. (2018). Pengaruh Efikasi Diri Siswa Dan Metode Mengajar Guru Terhadap Motivasi Belajar Siswa Kelas X Pada Mata Pelajaran Administrasi Umum Di Smk Abdi Negara Muntilan Tahun Ajaran 2017/2018, 313(3), 313-321.

Ghozali. (2011). Aplikasi Analisis Multivariate Dengan Program SPSS. Semarang: Universitas 
Vol. 1 No. 2 (Mei 2021) (305-323)

Diponegoro.

Nurmayanti, N. (2019). Pengaruh Religiusitas dan Tingkat Pendidikan Orang Tua Terhadap Motivasi Belajar PAI. Journal of Chemical Information and Modeling, 53(9), 1689-1699.

Paiko, E., \& Afrila, D. (2018). Pengaruh Lingkungan Sekolah Terhadap Motivasi Belajar Siswa Kelas XII Di Sma Negeri 10 Kota Jambi Elok. Scientific Journals of Economic Education, 2(April), 36-45.

Pontoh, Z., \& Farid, M. (2015). Hubungan Antara Religiusitas dan Dukungan Sosial dengan Kebahagiaan Pelaku Konversi Agama. Persona:Jurnal Psikologi Indonesia, 4(1), 100110.

Setyaningsih, S., Setiani, F., \& Jayadi. (2019). Pengaruh Perhatian Orang Tua terhadap Motivasi Belajar Siswa pada SMA Negeri 2 Sampit. Jurnal Paedagogie STKIP Muhammadiyah Sampit, VII(1), 47-54.

Setyaningsih, S., Setiani, F., \& Jayadi. (2019). Pengaruh Perhatian Orang Tua terhadap Motivasi Belajar Siswa pada
SMA Negeri 2 Sampit. Jurnal Paedagogie STKIP Muhammadiyah Sampit, VII(1), 47-54.

Sholibat, R. indriani. (2015). Pengaruh Efektivitas Peraturan Sekolahdan Fasilitas Belajar Terhadap Motivasi Dan Disiplin Belajar Serta Implikasinya Pada Hasil Belajar Siswa Pada Mata Pelajaran Ips (Survey Pada Smp Negeri Klasifikasi SSN di Kabupaten Bandung Barat). Jurnal Penelitian Pendidikan, 15(3).

Sulistyowati, E. D. (2016). Hubungan antara kematangan emosi dan keharmonisan keluarga dengan motivasi belajar siswa kelas viii di smp iss jatipurno wonogiri.

Ulfah, S. A., \& dan Syahrizaldi. (2017). Perbedaan Kematangan Emosi Ditinjau dari Jenis Kelamin pada Remaja di SMAS Sinar Husni Medan. Jurnal Diversita, 3(2), 59-65.

Wahid, F. S., Setiyoko, D. T., Riono, S. B., \& Saputra, A. A. (2020). Pengaruh Lingkungan Keluarga Dan Lingkungan Sekolah Terhadap Prestasi Belajar Siswa. Syntax Literate; Jurnal Ilmiah Indonesia, 5(8), 555. 